\title{
MEGAPOROMYA REYMENTI GEN. ET SP. NOV. (BIVALVIA, PHOLADOMYIDA) FROM THE UPPER TURONIAN (UPPER CRETACEOUS) OF THE SERGIPE BASIN, NORTH-EASTERN BRAZIL
}

\author{
WAGIH S. AYOUB-HANNAA \\ Geology Department, Faculty of Science, Minufiya University, El-Minufiya, Shibin El Kom, Egypt \\ wagih_hannaa@yahoo.com \\ PETER BENGTSON \\ Institut für Geowissenschaften, Im Neuenheimer Feld 234, 69120, Heidelberg, Germany \\ peter.bengtson@geow.uni-heidelberg.de
}

FRANZ T. FÜRSICH

GeoZentrum Nordbayern, Fachgruppe PaläoUmwelt, Friedrich-Alexander Universität Erlangen-Nürnberg Loewenichstr. 28, 91054, Erlangen, Germany

franz.fuersich@gzn.uni-erlangen.de

EDILMA DE JESUS ANDRADE

Núcleo de Geologia, Universidade Federal de Sergipe, Cidade Universitária, Campus Prof. José Aloísio de Campos, Av. Marechal Rondon s/nº, 49100-000, São Cristovão, SE, Brazil

edilmaa@gmail.com

\begin{abstract}
Megaporomya, a new genus of the bivalve family Poromyidae (order Pholadomyida), is erected and the type species Megaporomya reymenti gen. et sp. nov. described from the upper Turonian of the Cotinguiba Formation, Sergipe Basin, north-eastern Brazil. The main morphological features of the new genus are the large to very large shell, wide umbonal area, large posterior gape, strongly inflated valves, and faint, irregular commarginal ribs crossed by radial tubercles. The hinge of the right valve consists of one large, inverted, U-shaped cardinal tooth, one straight and narrow cardinal tooth and two unequal sockets. M. reymenti gen. et sp. nov. differs from other related species from the Cretaceous of Sergipe by its large size, surface ornamentation, valve inflation, and hinge features. The life position of $M$. reymenti gen. et sp. nov. is reconstructed on the basis of a functional interpretation of its morphology and by comparison with closely related Recent forms. Megaporomya gen. nov. was a semi-infaunal selective predator which probably fed on crustaceans and burrowed in soft sediments, extending slightly above the sediment-water interface. It detected its prey with the help of specialized tentacles surrounding the large inhalant siphon. The palaeoenvironmental setting of the Sergipe Basin during the late Turonian is interpreted on the basis of the associated fauna and facies.
\end{abstract}

Key words: bivalves, Megaporomya reymenti gen. et sp. nov., palaeoecology, Upper Cretaceous, Sergipe Basin, Brazil.

RESUMO - Megaporomya é um novo gênero da família Poromyidae (ordem Pholadomyida, Bivalvia) designado a partir da espécie-tipo Megaporomya reymenti gen. et sp. nov., descrita do Turoniano superior da Formação Cotinguiba da bacia de Sergipe, nordeste do Brasil. As principais características morfológicas do novo gênero são: concha de tamanho grande a muito grande, área umbonal ampla, abertura posterior grande, valvas fortemente infladas, costelas comarginais fracas e irregulares atravessadas por tubérculos radiais, e a presença na valva direita de um dente cardinal grande, invertido, em forma de U, um dente reto e delgado e duas fossetas desiguais. M. reymenti gen. et sp. nov. difere de outras espécies aparentadas do Cretáceo de Sergipe pelo seu tamanho, ornamentação, valvas muito infladas e características da charneira. O modo de vida de $M$. reymenti gen. et sp. nov. foi interpretado a partir da morfologia da concha e comparação com formas recentes. Megaporomya gen. nov. era um predador semi-infaunal seletivo, que provavelmente se alimentava de crustáceos e se enterrava em substratos moles, estendendo-se pouco acima da interface água-sedimento. Detectava suas presas com ajuda de tentáculos especializados, localizados ao redor do grande sifão inalante. O paleoambiente da bacia de Sergipe, durante o final do Turoniano, foi interpretado com base na fauna associada e facies sedimentar.

Palavras-chave: biválvios, Megaporomya reymenti gen. et sp. nov., paleoecologia, Cretáceo Superior, bacia de Sergipe, Brasil.

\section{INTRODUCTION}

The Cenomanian to lower Coniacian Cotinguiba Formation of the Sergipe Basin in north-eastern Brazil contains a rich macroinvertebrate fauna dominated by molluscs. Ammonites and bivalves are generally the most common and diverse groups. Koutsoukos \& Bengtson (1993) pointed out a number of problems in establishing a macrofossil 
zonation for the Sergipe Basin, which are mainly due to the discontinuous and small outcrops (normally only a few metres of section or less) in relation to the total thickness of the succession (well over $500 \mathrm{~m}$ ). This, in combination with local shifts in strike and dip, makes stratigraphic positioning of individual specimens difficult.

The Cretaceous macrofauna of Sergipe was initially monographed by White (1887) and Maury $(1925,1937)$ and subsequently, particularly in the past decades, has been the subject of taxonomic and biostratigraphic revision. Bengtson (1983) pointed out that the ages of specimens given by the earlier workers are often uncertain because of imprecise locality indications. In the past decades, studies have been carried out on different groups of bivalves from the Cotinguiba Formation, such as inoceramids, oysters, pinnids and pectinids (e.g. Hessel, 1985, 1988; Seeling, 1999; Seeling \& Bengtson, 1999, 2003a, b; Andrade et al., 2004; Andrade, 2005; Andrade \& Santos, 2011). In particular, members of the order Pholadomyida are abundant and well-preserved, though as yet poorly investigated.

Bengtson (1983), Kauffman \& Bengtson (1985), Hessel (1988), Smith \& Bengtson (1991), Koutsoukos \& Bengtson (1993), Seeling (1999), Seeling \& Bengtson (1999), Andrade (2005) and Bengtson et al. (2005) contributed to establishing a biostratigraphic scheme for the Cenomanian-Coniacian interval of the basin on the basis of ammonites, inoceramid bivalves, and foraminifers. The most detailed biostratigraphic zonation is based on ammonites, which enable a subdivision of the succession into seven biozones.

The purposes of this paper are (i) to erect the new poromyid bivalve genus Megaporomya and to compare it with the morphologically closest genera of the family Poromyidae, (ii) to describe the new species Megaporomya reymenti from the upper Turonian of the Sergipe Basin, (iii) to reconstruct the growth position and autecology of Megaporomya gen. nov., and (4) to reconstruct the palaeoenvironmental setting of the Sergipe Basin during the late Turonian on the basis of facies relationships and associated faunal elements, such as inoceramids, pinnids, gastropods and echinoids.

\section{GEOLOGICAL SETTING}

The Sergipe Basin is situated in the eastern, coastal part of the state of Sergipe in north-eastern Brazil. It comprises an area of approximately $11,000 \mathrm{~km}^{2}$, of which $6,000 \mathrm{~km}^{2}$ are onshore (Figures 1A,B). Structurally, the basin forms a sub-basin of the Sergipe-Alagoas Basin, which comprises, from north to south, the Cabo, Alagoas, Sergipe, and Jacuípe sub-basins (Souza-Lima et al., 2002). The localities where the specimens were collected are indicated in Figure 1C.

The Sergipe Basin is one of the numerous extensional rift basins bordering the South Atlantic Ocean, which were formed during the late Mesozoic rifting and separation of South America and Africa. The basin forms a half-graben bounded to the south-east by the continental slope and to the north-west by a system of normal faults. The geological evolution and the development of the marine Cretaceous of the Sergipe Basin have been discussed by several authors, (e.g. Ojeda \& Fugita (1976), Ojeda (1982), Bengtson (1983), Koutsoukos \& Bengtson (1993), Koutsoukos et al. (1993), Feijó (1995) and Souza-Lima et al. (2002)).

\section{STRATIGRAPHY}

The sedimentary fill of the Sergipe Basin varies in thickness between 1 and $3 \mathrm{~km}$ onshore, whereas offshore it may reach $8 \mathrm{~km}$ (Ponte et al., 1980). The Cretaceous succession (Figure 2A) consists of non-marine clastic deposits overlain by the marine, dominantly carbonate Riachuelo (Aptian-Albian) and Cotinguiba (CenomanianConiacian) formations and the siliciclastic Calumbi Formation (Santonian-Miocene) (Feijó, 1995; Souza-Lima et al., 2002). The thickness of the Cotinguiba Formation averages $200 \mathrm{~m}$ but may reach over $1000 \mathrm{~m}$ in the onshore part of the basin (Schaller, 1970). The rocks consist mainly of grey to blue-grey (cream or yellowish where weathered), fine-grained, massive, bioturbated limestones with sparse siliciclastic intercalations at the base of the formation (Bengtson, 1983). The Cotinguiba succession accumulated on a carbonate ramp system in neritic to upper bathyal environments with intermittent dysoxic-anoxic bottom conditions and well-oxygenated epipelagic waters (Koutsoukos et al., 1991, 1993).

The ammonite zonation used herein (Figure 2B) is that of Smith \& Bengtson (1991), Koutsoukos \& Bengtson (1993), Seeling \& Bengtson (1999) and Bengtson et al. (2005). The specimens were collected from quarries exposing the upper Turonian Barroisiceras onilahyense-Forresteria and Forresteria armata-Prionocycloceras lenti zones (Figure 2B). Because the stage boundary has not yet been definitely identified in the Sergipe Basin (Bengtson et al., 2005; Andrade, 2005), the possibility that some specimens may be of early Coniacian age should not be excluded. The specimens occur associated with other benthic macrofaunal elements such as inoceramid and pinnid bivalves, gastropods and irregular echinoids.

Bengtson (1983) provided a summary of the literature on the Cenomanian-Coniacian succession of the basin. More recent data are found, for example, in Andrade (2005).

\section{MATERIAL AND METHODS}

The specimens described here derive from fieldwork in the Sergipe Basin by P. and S.I. Bengtson in 1971-1972, with complementary sampling by P. Bengtson in 1977 and E.J. Andrade in 2001-2004. For details of the fieldwork, see Bengtson (1983) and Andrade (2005). A total of 75 specimens from nine localities, all quarries, are studied here (Figure 1C). Localities Cajaíba 7, Mata 9, Mata 10, Mucuri 7, Mucuri 10, Mucuri 12, Oiteiro 8 and Oiteiro 17 are described in Bengtson (1983, Appendix 1) and Mata 11 in Seeling (2004), Andrade (2005) and Manso \& Andrade (2008). Two of the specimens were collected in 1969 by R.A. Reyment (Uppsala University, Sweden) from locality "1/19", a quarry in the Mucuri area (Reyment \& Tait, 1972), probably Mucuri 7. 
As explained by Bengtson (1983, p. 29), most of the specimens were collected by quarry workers from unknown horizons within the quarries. However, owing to the small thicknesses of exposed successions (generally less than 20 $\mathrm{m})$, in relation to the total thickness of the succession, and the absence of unconformities, specimens from the same locality can be assumed to be of approximately the same age. Preservation is variable; in most cases the specimens are preserved as composite or internal moulds showing ornamentation and even muscle insertion areas. In a few cases, parts of the originally aragonitic shell are preserved, recrystallized as calcite.

The specimens were prepared mechanically, cleaned, and photographed. Silicone rubber moulds were made to enable study of the hinge structure of the valves.

A principal components analysis (PCA) was carried out to clarify the morphological relationship between the three distinct morphs of the new species Megaporomya reymenti. The analysis was performed using the PAST software, version 2.07 (Hammer et al., 2001) on a variance-covariance matrix of the log-transformed variables.

The systematic classification follows Bieler et al. (2010) and the morphological terminology that of Cox (1969, p. 102-109).

Linear measurements (taken with a Vernier caliper) are in millimetres. Orientation of measurements is shown in Figures 3A,B. Abbreviations for dimensions are as follows: $\mathbf{L}$, shell length; $\mathbf{H}$, shell height; $\mathbf{W}$, width of articulated valves; $\mathbf{C}$, convexity of valves; $\mathbf{A l}$, anterior length (measured from the umbones to the anterior margin); Hs, height of siphonal gape (measured perpendicular to the hinge axis). For measurements of individual specimens, see Appendix.

The holotype and paratypes are kept in the collections of the Museu Nacional in Rio de Janeiro, Brazil (MN). Additional specimens are housed in the Staatliches Museum für Naturkunde Karlsruhe, Germany (SMNK-PAL).

\section{SYSTEMATIC PALAEONTOLOGY}

\author{
Class BIVALVIA Linnaeus, 1758 \\ Subclass AUTOBRANCHIA Grobben, 1894 \\ Superorder HETEROCONCHIA Gray, 1854 \\ Order PHOLADOMYIDA Newell, 1965 \\ [= ANOMALODESMATA Dall, 1889] \\ Clade SEPTIBRANCHIA \\ Superfamily POROMYOIDEA Dall, 1886 \\ Family POROMYIDAE Dall, 1886
}

Genus Megaporomya gen. nov.

Type species. Megaporomya reymenti gen. et sp. nov. from the upper Turonian (Upper Cretaceous) of the Sergipe Basin, Brazil.

Etymology. Megas (Greek) = large, referring to the very large shell. Poromya (fem.): for the family Poromyidae, to which the new genus belongs.
Diagnosis. Thin-shelled, large to very large; variable in outline; strongly inflated anteriorly (cordate in cross-section), posteriorly elongate and compressed; umbones wide, strongly convex, enrolled; posterior siphonal gape wide; anisomyarian with shallow pallial sinus; hinge of right valve consisting of one large, inverted, U-shaped cardinal tooth, one straight and narrow cardinal tooth and two unequal sockets; hinge of left valve with two unequal teeth and sockets.

Species included. Megaporomya reymenti gen. et sp. nov., probably Isocardia supermensa White, 1887, and Liopistha (Psilomya) walkeri Whitney, 1952.

Remarks. The Sergipe specimens are placed in the family Poromyidae on the basis of (i) their very thin shells, (ii) a sub-truncated and sloping posterior margin, (iii) the presence of granules arranged in radial rows, and (iv) a posterior umbonal ridge, which separates the posterior flank from the rest of the shell.

Comparison with other genera. Megaporomya gen. nov. differs from other genera of the family Poromyidae (e.g. Poromya Forbes, 1844; Liopistha Meek, 1864; Psilomya White, 1874; Cymella, Meek, 1864) in its exclusive combination of characters. These include the large to very large size, broad and distinct umbonal area, strong inflation, and the hinge structure. The hinge of the right valve of Megaporomya consists of one large, inverted, U-shaped cardinal tooth, one straight and narrow cardinal tooth and two unequal sockets. The hinge of the left valve possesses, correspondingly, two unequal teeth and sockets. In contrast, the hinge of the genus Liopistha is more complicated and composed of two large cardinal teeth with one thin, tooth-like partition in the right valve and one large and one small cardinal tooth with one thin, tooth-like partition in the left valve (Dhondt \& Jagt, 1989, p. 489, pl. 1, fig. 7; pl. 2, fig. 1). According to Yonge $\&$ Morton (1980), the hinge of Poromya has simple teeth, which are presumed to be secondary. Megaporomya gen. nov. is ornamented with fine, irregular commarginal ribs separated by wide interspaces bearing fine growth lines. The commarginal ribs are crossed by widely spaced radial rows of minute tubercles (tuberculate appearance). In Liopistha, radial and commarginal ribs are equally developed, but towards the ventral margin only the radial ornamentation remains.

Compared to Megaporomya, Psilomya is characterized by a less developed radial ornamentation. The commarginal ribs of Megaporomya are less pronounced than in Cymella, where they cover the entire surface and are crossed by less developed radial ribs on the central part of the valve. Other diagnostic features of Megaporomya include shell size and inflation; the genus is much larger and more inflated than Liopistha and related genera.

Megaporomya gen. nov. is similar to the genus Pholadomyocardia Szajnocha, 1889 (family Ceratomyidae Arkell, 1934) in having strongly inflated valves, a wide umbonal area, and a truncated anterior margin, but differs in lacking the wing-like postero-dorsal extension and in possessing a radial ornamentation, whereas in Pholadomyacardia the surface is ornamented with only a few commarginal ridges (concentric rugae). 

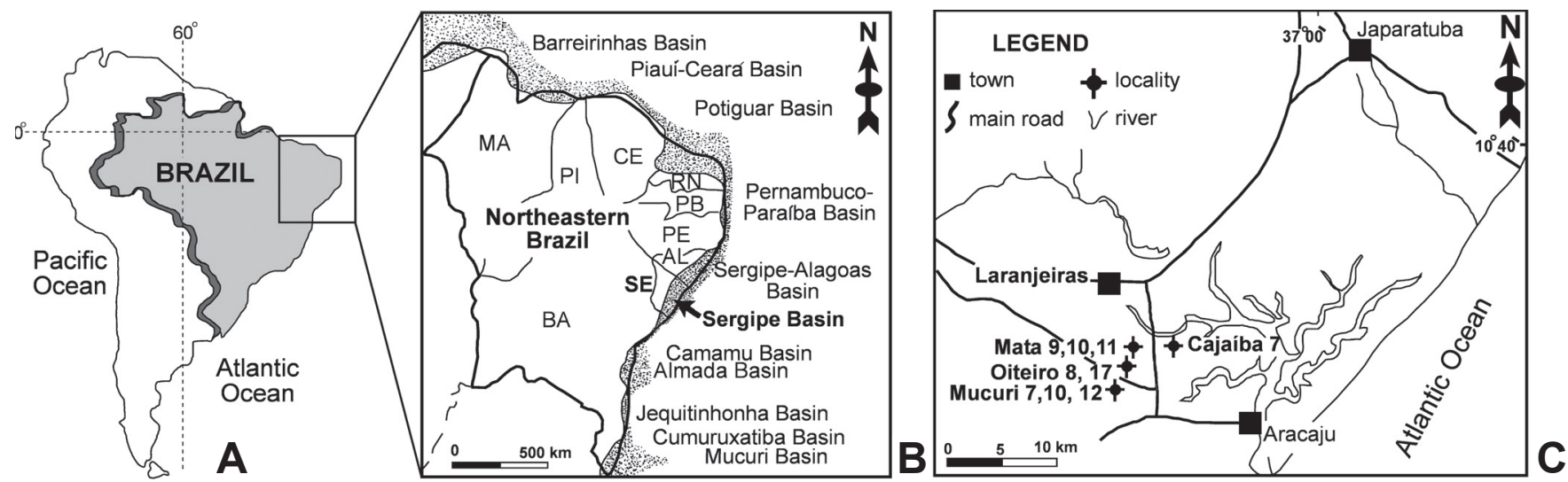

Figure 1. A-B, location of the Sergipe Basin and adjacent continental margin basins. C, map of central part of the Sergipe Basin showing localities with Megaporomya reymenti gen. et sp. nov. Abbreviations: AL, Alagoas; BA, Bahia; CE, Ceará; MA, Maranhão; PB, Paraíba; PE, Pernambuco; PI, Piauí; RN, Rio Grande do Norte; SE, Sergipe (modified from Seeling \& Bengtson, 2003a).

Stratigraphic range. Megaporomya gen. nov. is so far recorded with certainty only from the upper Turonian.

\section{Megaporomya reymenti gen. et sp. nov.}

(Figures 4-6, 9)

v1983 Liopistha (Psilomya) supermensa White [sic]. Bengtson, p. 47.

v2005 Psilomya ligeriensis (d'Orbigny, 1845). Andrade, p. 49. v?2011 Liopistha (Psilomya) supermensa (White, 1887). Andrade \& Santos, p. 234, figs. 2: 5-7.

v?2011 Liopistha (Psilomya) ligeriensis (d'Orbigny, 1945 [sic]). Andrade \& Santos, p. 233-234, figs. 2:3-4.

Etymology. Named after Professor Richard A. Reyment (Uppsala University, Sweden), who in 1969 collected two well-preserved specimens from locality " $1 / 19$ " in the Mucuri area, probably Mucuri 7 (specimens MN 8748-I and MN 8749-I herein); see Reyment \& Tait (1972).

Diagnosis. Megaporomya with large to very large valves $(\mathrm{L}=c$. $85-150 \mathrm{~mm})$, elongate-ovate to ovate; oblong or rounded $(\mathrm{H} / \mathrm{L}=$ c. 0.6-1.0); strongly inflated $(\mathrm{W} / \mathrm{L}=c$. 0.6-0.9); sub-truncated to slightly convex anterior margin, meeting the ventral margin in a blunt angle; posterior margin sub-truncated and sloping; anterior umbonal ridge moderately well-developed, forming boundary of shallow depression on anterior part; posterior umbonal ridge faint, separating concave posterior flank from rest of shell; commarginal ribs irregular, crossed by radial rows of minute tubercles (tuberculate appearance).

Holotype. Composite internal mould of articulated specimen no. MN 8711-I (Figures 4A,B) collected by E.J. Andrade in 2003 from the upper Turonian of locality Mata 11, Cotinguiba Formation, Sergipe Basin, Brazil.

Paratypes. 38 composite and internal moulds (MN 8712-I-8749-I) of articulated specimens illustrated in Figures 5A-F, 6A, and 9C from the upper Turonian of localities Mucuri 7, 10, 12 and Mata 11, Sergipe Basin, Brazil.

Other material. 36 composite and internal moulds (SMNKPAL 11001-11036) from the upper Turonian of localities
Cajaíba 7, Mata 9, 10 and Oiteiro 8, 17, Cotinguiba Formation, Sergipe Basin, Brazil.

Type locality. Mata 11 (Nassau Quarry), $12 \mathrm{~km}$ northwest of Aracaju, Sergipe Basin, Brazil (Figure 1C; described in detail by Seeling, 2004; Andrade, 2005; Manso \& Andrade, 2008).

Type horizon. Forresteria armata-Prionocycloceras lenti Zone, upper Turonian, Cotinguiba Formation.

Measurements. See Table 1 and Appendix.

Description. Large to very large $(\mathrm{L}=85-150 \mathrm{~mm})$ shell, varying in outline from elongate-ovate to broadly ovate or rounded, slightly equivalved, strongly inequilateral, strongly inflated $(\mathrm{W} / \mathrm{L}=0.74$ on average $)$ and posteriorly elongate $(\mathrm{H} / \mathrm{L}=0.80$ on average). Maximum inflation below the umbones; shell slightly compressed posteriorly. Anterodorsal margin slightly convex, meeting the anterior margin in a rounded angle. Anterior margin sub-truncated to slightly convex, meeting the ventral margin in a blunt, nearly right angle (Figure 5D). Postero-dorsal margin slightly convex, slightly sloping, forming an obtuse angle with the posterior margin. Posterior margin obliquely truncated, forming an acute angle with the ventral margin. Posterior end strongly gaping. Ventral margin irregularly broad, slightly convex. Rounded ridge extending from front of umbones to middle of anterior margin, forming boundary of shallow depression on anterior part (Figure 4B). Posterior concave area (10-17\% of total valve length from posterior end) separated from rest of shell by a faint posterior umbonal ridge. Umbonal area wide and strongly convex. Lunule cordate in outline, wide, and shallow. Umbones large, prominent, pointed, enrolled, elevated above hinge line and slightly incurved anteriorly. Hinge of right valve consisting of one large, inverted, U-shaped cardinal tooth, one straight and narrow cardinal tooth and two unequal sockets (Figures 5C; 8A-C). Hinge of left valve with two unequal teeth and sockets. Posterior adductor muscle scar elongate ovate, larger than anterior muscle scar, located near postero-dorsal side; anterior scar circular to oval, located antero-dorsally (Figure 8D). Small anterior and posterior pedal retractor muscle scars attached to respective adductor scars. Pallial line oblique to ventral margin, 


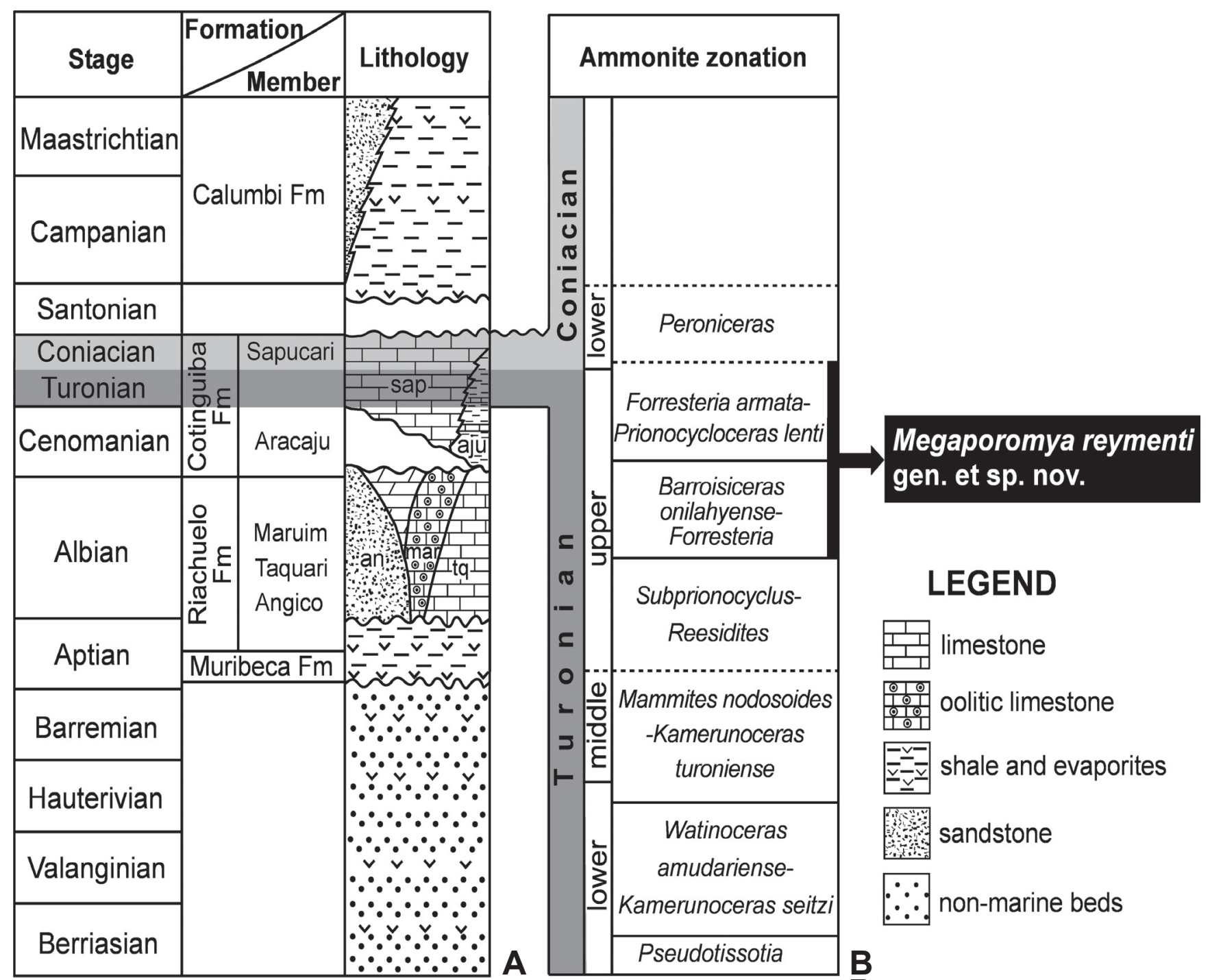

Figure 2. A, Simplified Cretaceous stratigraphic framework for the Sergipe Basin (modified from Bengtson, 1983; Hessel, 1988; Smith \& Bengtson, 1991; Feijó, 1995; Souza-Lima et al., 2002). B, Ammonite zonation for the Turonian-Coniacian of Sergipe (after Smith \& Bengtson, 1991; Koutsoukos \& Bengtson, 1993; Seeling \& Bengtson, 1999; Bengtson et al., 2005).
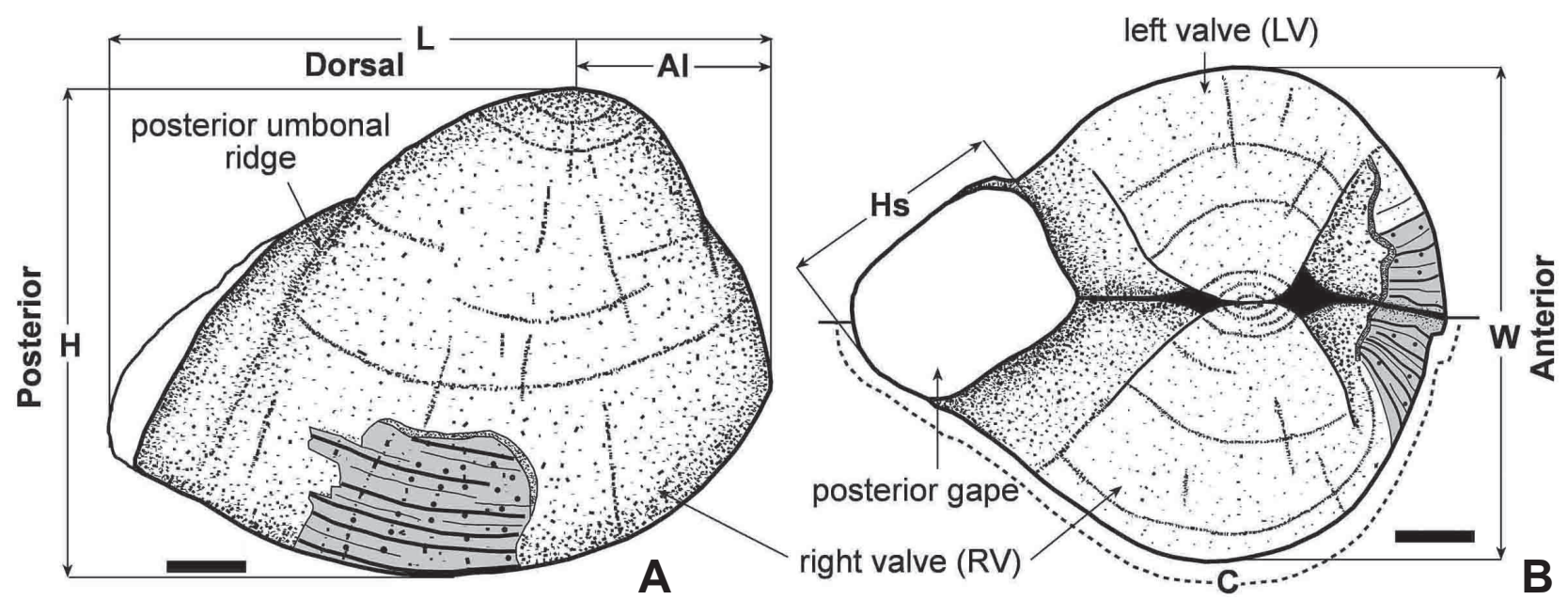

Figure 3. Measured parameters of Megaporomya reymenti gen. et sp. nov. A, lateral view of right valve; B, dorsal view. The grey parts refer to preserved shell material. Abbreviations: L, shell length; $\mathbf{H}$, shell height; $\mathbf{W}$, width of articulated valves; $\mathbf{C}$, convexity of valve; $\mathbf{A l}$, anterior length; Hs, height of siphonal gape. Scale bars $=20 \mathrm{~mm}$. 
Table 1. Dimension ranges (in $\mathrm{mm}$ ) of Megaporomya reymenti gen. et sp. nov. For abbreviations, see Figure 3.

\begin{tabular}{lcccccccccc}
\hline $\mathrm{n}=58$ & $\mathrm{~L}$ & $\mathrm{H}$ & $\mathrm{W}$ & $\mathrm{Al}$ & $\mathrm{Hs}$ & $\mathrm{C}$ & $\mathrm{H} / \mathrm{L}$ & $\mathrm{Al} / \mathrm{L}$ & $\mathrm{W} / \mathrm{L}$ \\
\hline Range & $85-150$ & $73-113$ & $60-105$ & $10-45$ & $47-83$ & $113-180$ & $0.61-0.98$ & $0.09-0.63$ & $0.61-0.93$ \\
Mean & 114.89 & 91.15 & 84.45 & 29.48 & 64.46 & 147.96 & 0.80 & 0.26 & 0.74 \\
\hline
\end{tabular}

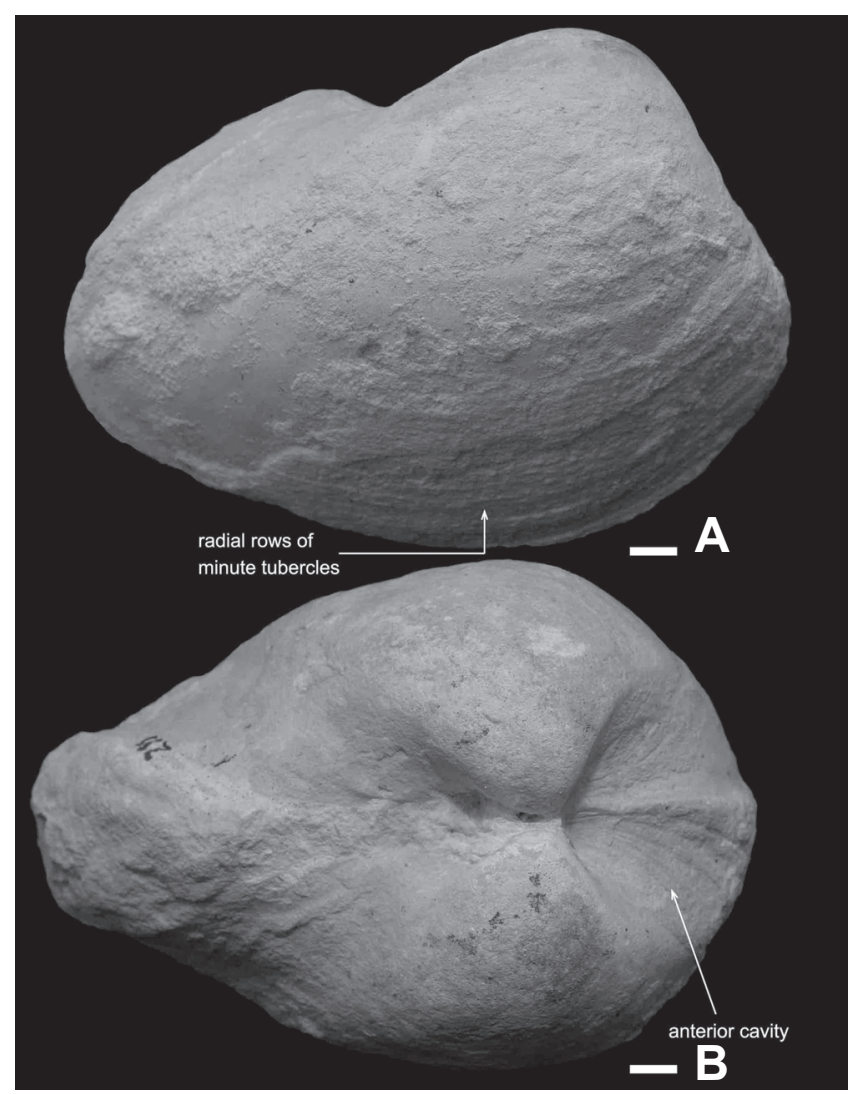

Figure 4. Megaporomya reymenti gen. et sp. nov. from the upper Turonian of the Cotinguiba Formation, Sergipe Basin (elongate form); holotype, no. MN 8711-I, from Mata 11. A, right lateral view of the articulated composite mould, showing radial rows of minute tubercles; B, dorsal view showing the strongly inflated valves and the anterior depression. Scale bars $=10 \mathrm{~mm}$.

with faint posterior sinus. Ornamentation consisting of fine commarginal ribs separated by wider interspaces. Interspaces carrying fine growth lines in some individuals (Figures 5D, F). Posterior area (near posterior end) smooth. Commarginal ribs well developed on dorsal area, crossed by widely spaced radial rows of minute tubercles. Radial tubercles becoming more prominent away from umbones towards ventral margin. Statistical analysis. Three morphs of Megaporomya reymenti are recognized mainly on the basis of variability in general outline ( $\mathrm{H} / \mathrm{L}$ ratio) and position of the umbones: elongate, suborbicular and intermediate forms. Principal Component Analysis (PCA) was performed to clarify the morphological relationship between the three forms on variance-covariance matrix of the following log-transformed variables: length (L), height $(\mathrm{H})$, width $(\mathrm{W})$, inflation $(\mathrm{C})$, and anterior length (Al). The first principal component (PC1) accounted for $73.81 \%$ of the variation in the data, PC2 accounted for $20.16 \%$, and PC3 accounted for $2.69 \%$ (Figure 7E). The original variables display a strong positive correlation with PC2 and, therefore, individuals with high PC2 scores have a large body size. The anterior length (Al) is positively correlated with the PC1 axis, individuals with high $\mathrm{PC} 1$ values having a large anterior part (Figures 7A,C). It can be seen that the three forms are similar in size but differ in general outline and length of the anterior area. The latter is confirmed by plotting of PC1 vs. $\mathrm{PC} 3$, where $\mathrm{PC} 3$ is positively correlated with the $\mathrm{H} / \mathrm{L}$ ratio; therefore, individuals with high $\mathrm{PC} 3$ values have a more rounded shell than those with low values. The suborbicular form is characterized by a large anterior part (umbones situated at approximately one-third of the total valve length from the anterior end), a sub-rounded outline, and by being taller $(\mathrm{H} / \mathrm{L}=0.80$ on average) (Figures $7 \mathrm{C}, \mathrm{D})$. In contrast, the elongate form is characterized by more elongate valves, sub-terminal umbones, a short anterior area and an expanded posterior area. However, as the three forms overlap (based on $\mathrm{Al} / \mathrm{L}$ and $\mathrm{H} / \mathrm{L}$ ratios), they are assigned to the same species (Figures 7A,B).

Discussion. Megaporomya reymenti is a variable species (elongate-ovate to ovate, rounded), characterized by very large, strongly inflated valves, a wide umbonal area, irregular commarginal ribs, crossed by radial rows of minute tubercles (Figures 4A, 6A), sub-terminal to nearly central umbones (located from one-fourth to more than one-third of the shell length from the anterior end), which are nearly in contact, a wide siphonal gape, and two cardinal teeth, one a large inverted U-shaped and one straight and narrow, and with two unequal sockets in the right valve.

The similar species Isocardia supermensa was described by White (1887, p. 80 , pl. 6, figs. 1-2) and redescribed by Maury (1937, p. 71, pl. 9, figs. 16-17) on the basis of a single, poorly preserved specimen presumed to derive from the Albian of the Sergipe Basin. Beurlen (1971) referred this species to Psilomya and dated it as Coniacian, and Seeling (1999) reported it from the Cenomanian-Turonian boundary beds of Sergipe. Lefranc (in Bengtson, 1983, Table 2) assigned the species to Liopistha (Psilomya). Here it is tentatively referred to Megaporomya on account of its size, sub-terminal umbones, wide umbonal area, and strong inflation. It differs from $M$. reymenti in having a strong antero-dorsal ridge, which extends from the umbones to the middle of the anterior margin and forms a deep anterior depression, terminal and strongly enrolled umbones, and in being smaller $(\mathrm{L}=80, \mathrm{H}=55$, $\mathrm{T}=62 \mathrm{~mm}$ fide Maury, 1937, p. 71. as opposed to $\mathrm{L}=115$, $\mathrm{H}=91, \mathrm{~T}=84$ on average for $M$. reymenti) and more elongate ( $\mathrm{L} / \mathrm{H}=1.45$ as opposed to $\mathrm{L} / \mathrm{H}=1.27$ on average). In addition, the specimen of M.? supermensa described by White (1887) and Maury (1937) lacks radial ornamentation, although this may be a preservational artefact. 


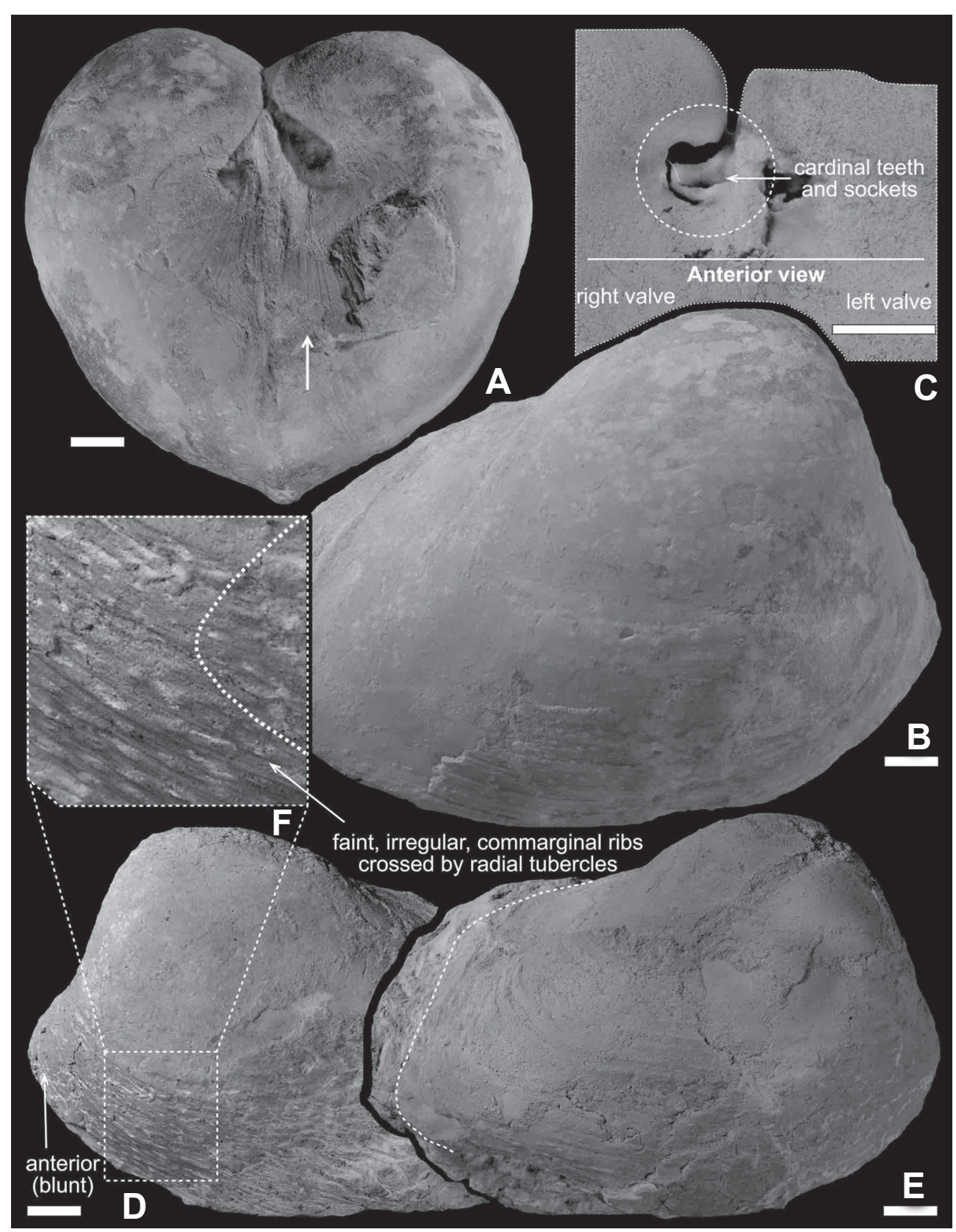

Figure 5. Megaporomya reymenti gen. et sp. nov. from the upper Turonian of the Cotinguiba Formation, Sergipe Basin (elongate form). A-B, articulated composite mould with remains of shell; paratype, no. MN 8748-I, from locality "1/19" of Reyment \& Tait (1972), Mucuri area, probably Mucuri 7. A, anterior view showing the strongly inflated valves with remains of shell (arrowed); B, side view of right valve; C, anterior view of articulated composite mould, no. SMNK-PAL 11034, from Mata 10, showing the upper and lower cardinal sockets with two unequal teeth; D-F, composite mould with remains of shell; paratype, no. MN 8722-I from Mucuri 10; D, side view of left valve; E, side view of right valve showing the truncated posterior end; F, close-up showing irregular commarginal riblets and well-developed radial tubercles. Scale bars $=10 \mathrm{~mm}$.

The specimens from localities Pedro Gonçalves 2 (lower or middle Turonian) and Mata 11 (upper Turonian), described and figured by Andrade \& Santos (2011) as Liopistha (Psilomya) supermensa (White, 1887) and Liopistha (Psilomya) ligeriensis (d'Orbigny, 1945 [sic]) probably belong to $M$. reymenti (specimen MT11-288, erroneously given as MT11-387 on p. 233), although some of their specimens of $L$. (P.) ligeriensis are considerably smaller $(\mathrm{L}=65 \mathrm{~mm})$ than the specimens described here. The true $L$. (P.) ligeriensis differs in being smaller and less inflated, in having numerous and fine commarginal ribs, and in lacking radial ribbing. Pervinquière (1912) and Barber (1958) considered Homomya profunda (White, 1887, p. 105, pl. 7, fig. 5) from the middle Albian of Sergipe as conspecific with $L$. (P.) ligeriensis. Andrade \& Santos (2011) followed Barber's opinion but their specimens differ in being much more inflated and larger $(\mathrm{L}=65-112, \mathrm{H}=64-102 \mathrm{~mm}$ as opposed to $\mathrm{L}=36, \mathrm{H}=30 \mathrm{~mm}$ ).

Liopistha (Psilomya) gigantea (Sowerby, 1818), as described and figured by Woods $(1909$, p. 257, pl. 43, 


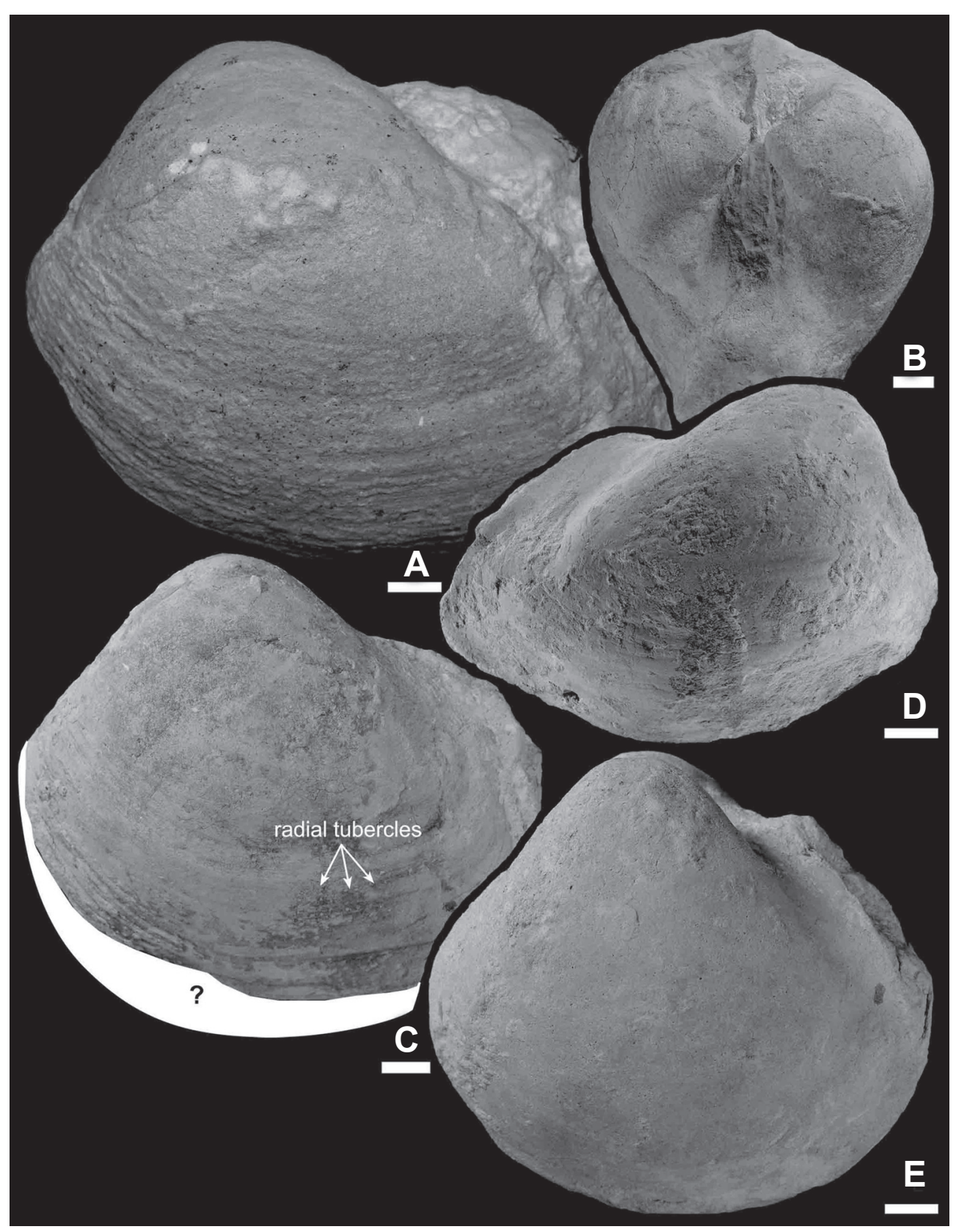

Figure 6. Megaporomya reymenti gen. et sp. nov. from the upper Turonian of the Cotinguiba Formation, Sergipe Basin (intermediate and suborbicular forms). A, Composite mould, side view of left valve, no. SMNK-PAL 11034, from Mata 10. B, Dorsal view of composite mould, no. SMNK-PAL 11022, from Mata 9. C, Left lateral view of composite mould, no. SMNK-PAL 11009, from Cajaíba 7. D, Right lateral view of composite mould; paratype, no. MN 8713-I, from Mucuri 10. E, Lateral view of left valve (rounded form) of composite mould; paratype, no. MN 8717-I, from Mucuri 10. Scale bars $=10 \mathrm{~mm}$.

figs. 3-4; pl. 44, figs. 1-2) from the Upper Cretaceous of England, strongly resembles $M$. reymenti in size and outline but differs in having a narrow umbonal area, numerous fine, dorsally well-developed commarginal ribs, less-developed radial tubercles, restricted to the anterior area, a rounded posterior margin and in lacking a postero-dorsal ridge.

Liopistha (Psilomya) walkeri Whitney (1952, p. 68, pl. 16, figs. 5,6 ) from the Albian of Texas is probably better referred to Megaporomya. The specimen is an internal mould without any trace of ornamentation and is too poorly preserved for species assignment. M.? walkeri is similar to M. reymenti in having a well-developed postero-dorsal ridge, truncated anterior margin, and a wide and rounded ventral margin, but differs in being less inflated, smaller $(\mathrm{L}=95 \mathrm{~mm}, \mathrm{H}=65 \mathrm{~mm}$, $\mathrm{W}=70 \mathrm{~mm}$ ) and more elongate. In addition, M.? walkeri is recorded from a lower stratigraphic level (Albian).

Poromya superba Stoliczka (1871, p. 48, pl. 3, figs. 2-4) from the Coniacian of India and Liopistha superba (Stoliczka, 1871) described and figured by Riedel (1932, p. 68, pl. 5, fig. 1) from the Santonian-Maastrichtian of Germany, resemble Megaporomya reymenti in size $(\mathrm{L}=100, \mathrm{H}=80 \mathrm{~mm}$; Stoliczka, 1871) but differ in having narrow, sharply pointed umbones, less 


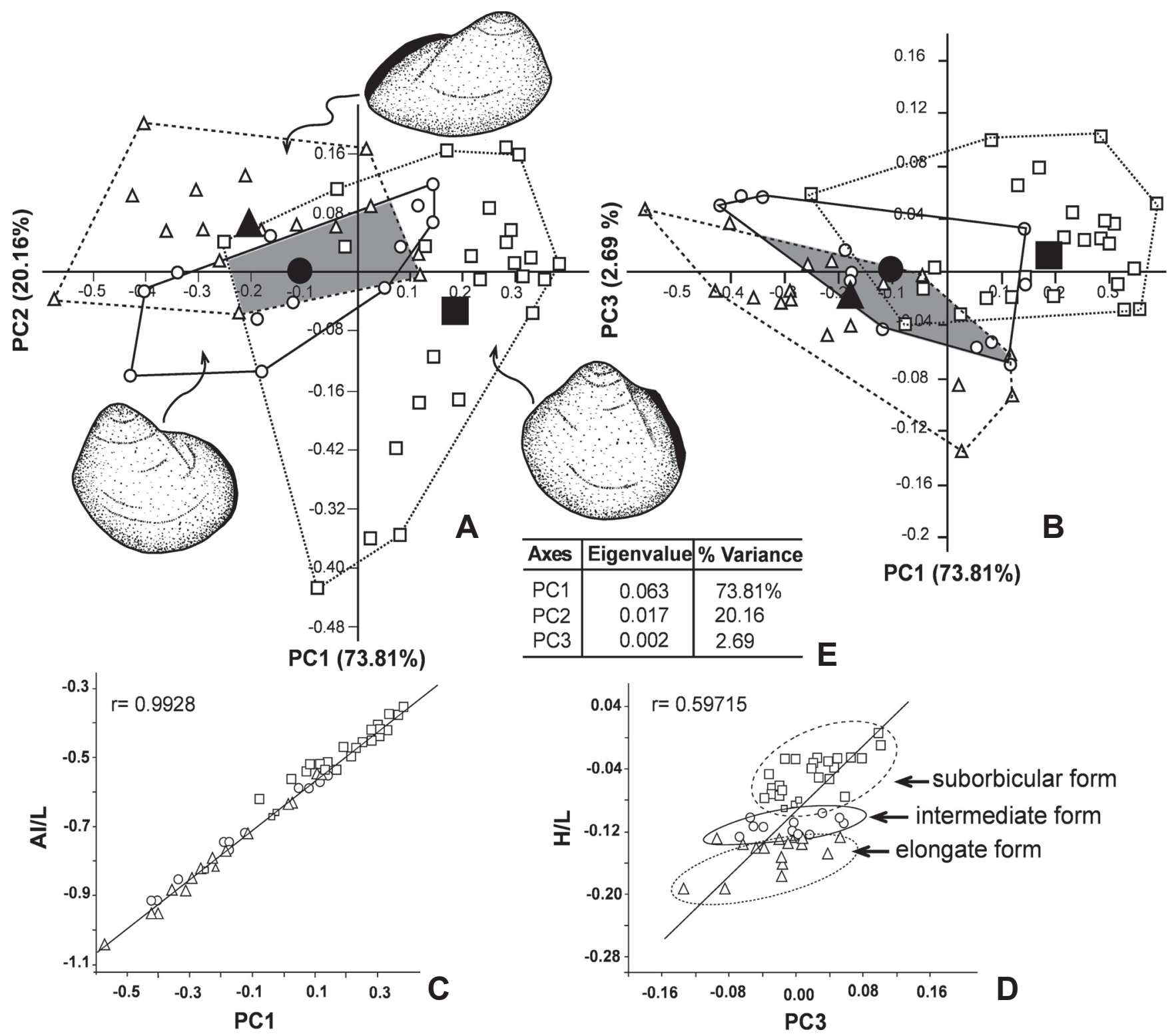

Figure 7. Principal component analysis (PCA) of Megaporomya reymenti gen. et sp. nov. using the PAST software (Hammer et al., 2001). A, scatter plot of PC1 vs. PC2 showing the overlapping of the three morphs, elongate, suborbicular and intermediate forms, of $M$. reymenti on the basis of Al/L ratio; B, scatter plot of PC1 vs. PC3 showing also the overlapping of the three morphs based on shell outline (H/L); C, relationship between $\mathrm{PC} 1$ and $\mathrm{Al} / \mathrm{L}$ showing that the elongate form has sub-terminal umbones (PC1 scores range from 0 to 0.1 ); $\mathbf{D}$, relationship between PC3 and shell outline $(\mathrm{H} / \mathrm{L})$ showing that the suborbicular form is taller than the elongate form (PC3 scores range from -0.04 to 16$)$; E, percentage of variation explained by PCA of body-size variables. The large symbols in the scatter plots represent the centroid value for the respective groups $(A$ and $B)$.

inflated valves, and numerous commarginal ribs crossed by radial tubercles on the anterior area. L. (P.) banderaensis (Whitney, 1952, p. 67, pl. 16:1-2) from the Albian of Texas differs in being less inflated $(\mathrm{W} / \mathrm{L}=0.55$ as opposed to 0.74 on average $)$ and in having circular posterior and anterior muscle scars and a narrow umbonal area. In addition, Whitney's specimen is an internal mould without any signs of ornamentation.

\section{PALAEOAUTECOLOGY}

Reconstructing life habits of fossil bivalves is generally difficult, because the soft parts are decayed and the original shell is often dissolved. However, it is possible to reconstruct life habits of extinct species by analogy with the mode of life of Recent relatives and, particularly where no close relatives exist today, by applying the principles of functional morphology (Fürsich, 1980, p. 289).

All representatives of the Pholadomyida are marine organisms, some of them adapted to burrowing to varying depths in soft sediment. The burrowing depth and the degree of mobility in the sediment can be roughly estimated from their shell morphology (Runnegar, 1974, p. 909). In fossil shells, the shape and size of adductor and pedal muscle scars in combination with the hinge structure may give indications 


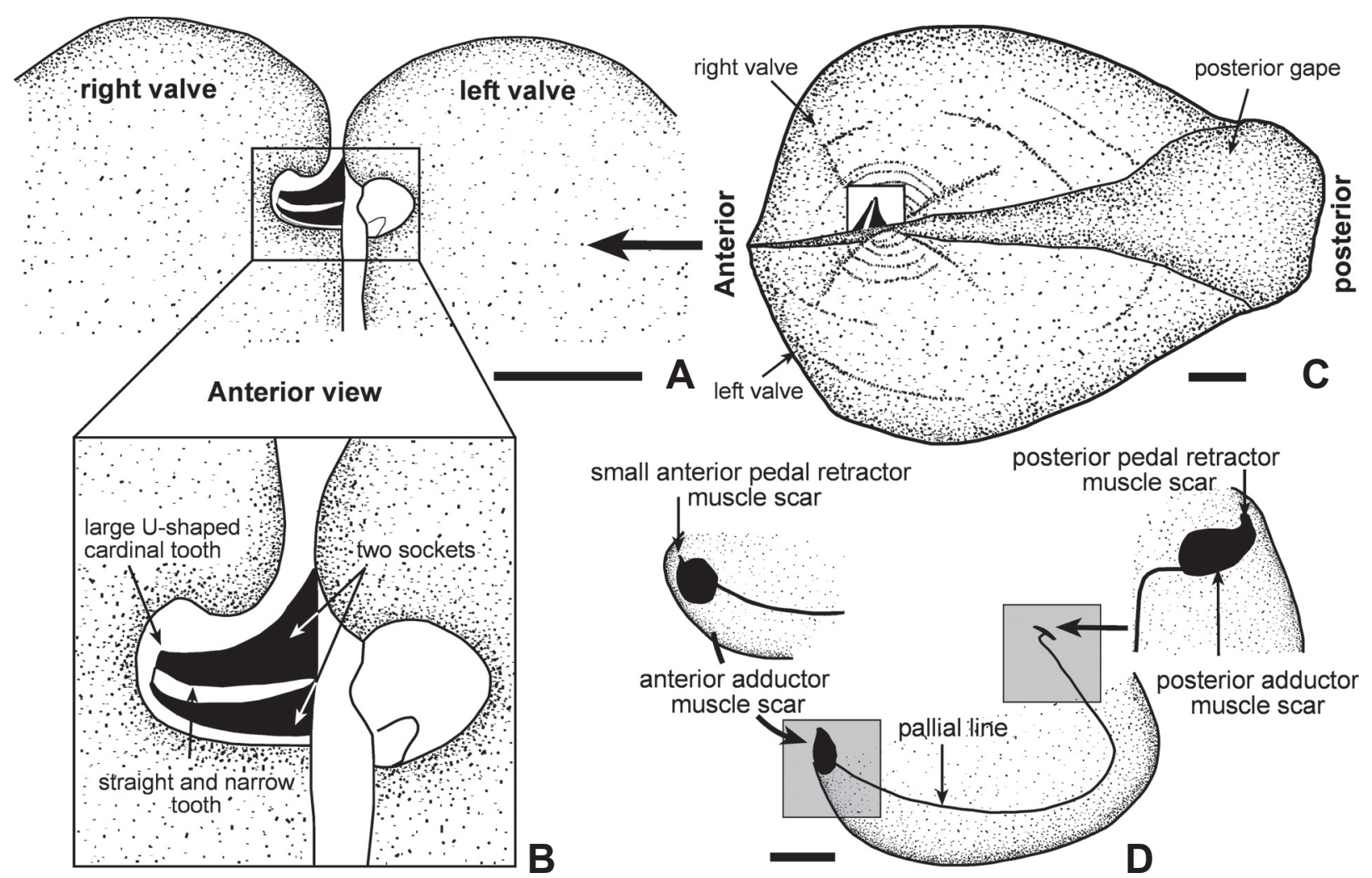

Figure 8. A-C, hinge structure of Megaporomya reymenti gen. et sp. nov. from the upper Turonian of the Cotinguiba Formation, Sergipe Basin. A-C, specimen no. SMNK-PAL 11034, from Mata 10. A, anterior view showing the cardinal teeth and sockets of the right valve; B, close-up showing the large, inverted, U-shaped tooth and the straight and narrow tooth with the two unequal sockets; C, dorsal view; D, adductor and pedal retractor muscle scars and pallial line of $M$. reymenti, paratype, no. MN8712-I, from Mucuri 10. Scale bars: $A, C=10 \mathrm{~mm}$; $D=20 \mathrm{~mm}$.

of an endobyssate or free-burrowing mode of life (e.g. Trueman, 1967; Stanley, 1972; Runnegar, 1974). With respect to feeding mode, representatives of several pholadomyid families live in the deep sea and have become carnivorous, showing remarkable morphological adaptations for the capture of small arthropods and polychaetes (Harper et al., 2006, p. 404). Species of the family Poromyidae are predators of crustaceans and/or polychaetes and show no evidence of vegetable matter in any part of the alimentary canal (e.g. Pelseneer, 1891; Yonge, 1928; Morton, 1981). According to Yonge (1928), Poromya slowly inhales small prey with the siphon, which projects only slightly above the sediment-water interface. The prey falls down onto the palps, which push it into the mouth. Morton (1981) and Allen \& Morgan (1981) examined the siphonal structure of two specimens of living Poromya granulata and found that the inhalant siphon is surrounded by 15 tentacles, each with sensory papillae. The prey is probably detected by the siphonal tentacles, which detect mechanical disturbance in the water. For more details about the feeding mechanism of the family Poromyidae, see Morton (1981, p. 253-254).

The most notable features of the genus Megaporomya are the very large shell, expanded posteriorly, the blunt anterior side, strongly inflated valves, strongly enrolled umbones, wide anterior face with shallow anterior depression and the commarginal ornamentation with radial tubercles. Burrowing was performed mainly by means of the foot, which could be extended ventrally or anteriorly (Yonge, 1928, p. 238). In vertical position, the posterior end of the valves was oriented upwards and the blunt anterior side was in wide contact with the substrate. By opening and closing the valves, Megaporomya could pull itself into soft sediments assisted by the acute antero-ventral margin. After the first step of burrowing, the bivalve changed to an oblique position and pushed itself downwards through jerking movements of the valves. According to Yonge (1928, p. 239), all movements of the extant Poromya are sudden with appreciable intervals. Finally, Megaporomya reached a depth at which the end of the postero-dorsal ridge was at or slightly extended above the sediment-water interface. The inhalant and exhalant siphons were never covered with sediment. The strongly convex valves with their radial rows of tubercles helped the bivalve to penetrate the soft substrate slowly. In addition, the function of the tubercles might have been to increase friction between the valves and sediment and so slowing down the burrowing rate. The commarginal ornamentation, albeit only moderately developed, most probably served to increase stability within the sediment (Stanley, 1970, 1972, 1975). According to Runnegar (1974, p. 916), prominent cardinal hinge teeth occur in several shallow-burrowing pholadomyid genera but very rarely in deep-burrowing genera. Additional evidence for the more or less vertical, shallow-infaunal growth position of Megaporomya is provided by the presence of serpulids and fragments of small bivalves, which encrusted only the 
posterior part of some specimens (one-sixth of the specimens; Figures 9A-D). In conclusion, based on analogy with modern relatives, Megaporomya is interpreted as a semi-infaunal to shallow-infaunal selective predator feeding on crustaceans and/or polychaetes (Figure 11A).

\section{PALAEOSYNECOLOGICAL REMARKS}

Megaporomya reymenti is recorded from the upper Turonian (with possible occurrences in the lower Coniacian). Co-occurring faunal elements are other bivalves (e.g. inoceramids, plicatulids, oysters, pinnids), gastropods, echinoids and ammonites. The dominant benthic organisms of this association are bivalves $(28 \%$ inoceramids and $44 \%$ other bivalves) and gastropods (24\%). According to Andrade (2005, p. 49, figs. 6.9a-c), inoceramids are abundant throughout the Turonian but rare where other bivalves are abundant, as observed in the upper Turonian of locality Mata 11 (Figure $10 \mathrm{~A})$. Echinoids are subordinate (4\%) with a monospecific occurrence of Mecaster fourneli. With respect to mode of life, the association contains a large number of shallow-infaunal (56\%) and epifaunal (44\%) organisms, whereas deeperinfaunal elements are absent (Figure 10B). Suspensionfeeders dominate $(72 \%)$, with carnivores and deposit-feeders as subordinate elements (16\% and 12\%, respectively; Figure 10C). The association occurs in fine-grained lime mudstones and wackestones (Smith \& Bengtson, 1991, p. 15). The pinnids are large $(\mathrm{L}=250 \mathrm{~mm})$, articulated, and embedded in life position, as indicated by the orientation of the long axis of the shells perpendicular to bedding (Seeling \& Bengtson, 2003a). Most of the pinnids show repair scars, indicating attacks by predators.

Koutsoukos et al. (1993) suggested that the CenomanianConiacian succession accumulated in a carbonate ramp system over a relatively wide continental shelf in neritic to upper bathyal (200-500 m) environments. The approximately equal abundance of shallow-infaunal and epifaunal organisms is evidence of a biota adapted to life on a moderately soft substrate under fully marine conditions (Figure 11B). Shallow-infaunal echinoids as well as ammonites (stenohaline groups) also document euhaline conditions. Using the morphology of echinoids as a tool for palaeoenvironmental reconstruction, Smith \& Bengtson (1991, p. 15) interpreted the poorly developed petals of Mecaster fourneli as an indication of relatively warm water conditions. With respect to the energy level, the presence of non-byssate to weakly byssate inoceramids, which lived as epifaunal recliners or semi-infaunally, suggests relatively quiet conditions (Elder, 1987). However, the dominance of suspension-feeders $(72 \%)$ indicates that the energy level was sufficiently high to keep food particles in suspension under relatively low sedimentation rates. In addition, a relatively stable, low-stress environment is corroborated by intermediate diversity values (Figure 11B). According to Andrade (2005, p. 126), based on

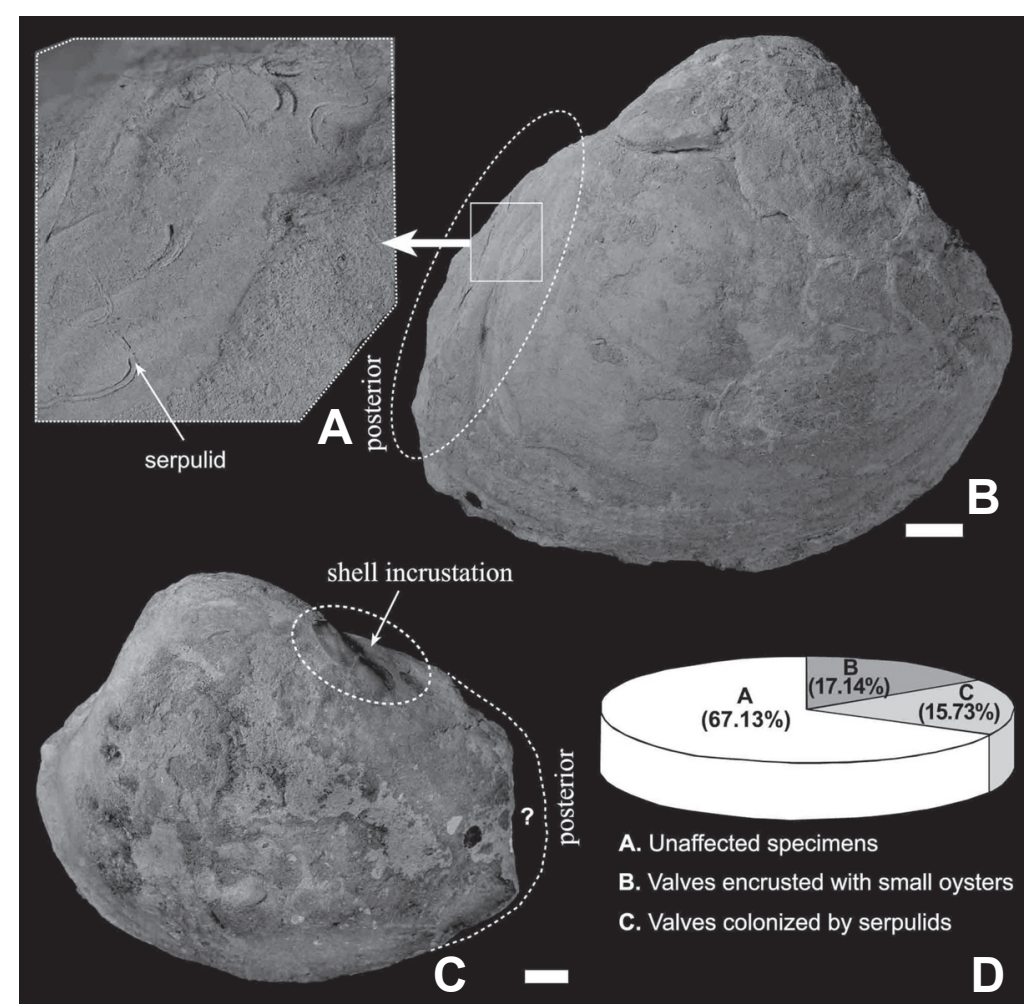

Figure 9. Megaporomya reymenti gen. et sp. nov. from the upper Turonian of the Cotinguiba Formation, Sergipe Basin. A-B, specimen no. SMNK-PAL 11032 from Mata 10; A, close-up showing the distribution of serpulids along the inner posterior side of the mould; B, composite mould of right valve; $\mathbf{C}$, composite mould of left valve showing remains of cemented shells along the posterior side of the valve; paratype, no. MN8718-I, from Mucuri 10; D, pie diagram showing the relative abundance of epi- and endobionts in the Megaporomya specimens studied. Scale bars $=10 \mathrm{~mm}$. 

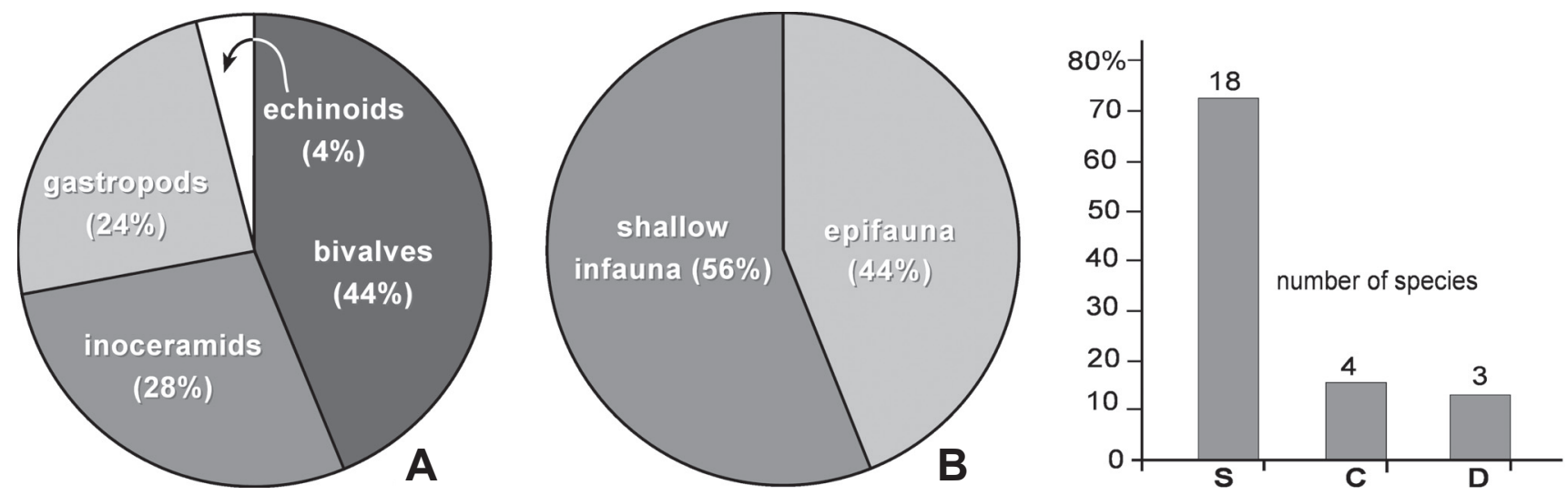

Figure 10. A-B, composition of the benthic macrofauna (number of taxa) from the uppermost Turonian of the Sergipe Basin; C, life habits and modes of feeding of the upper Turonian benthic macrofauna. Abbreviations: S, suspension-feeding; C, carnivorous; D, deposit-feeding.

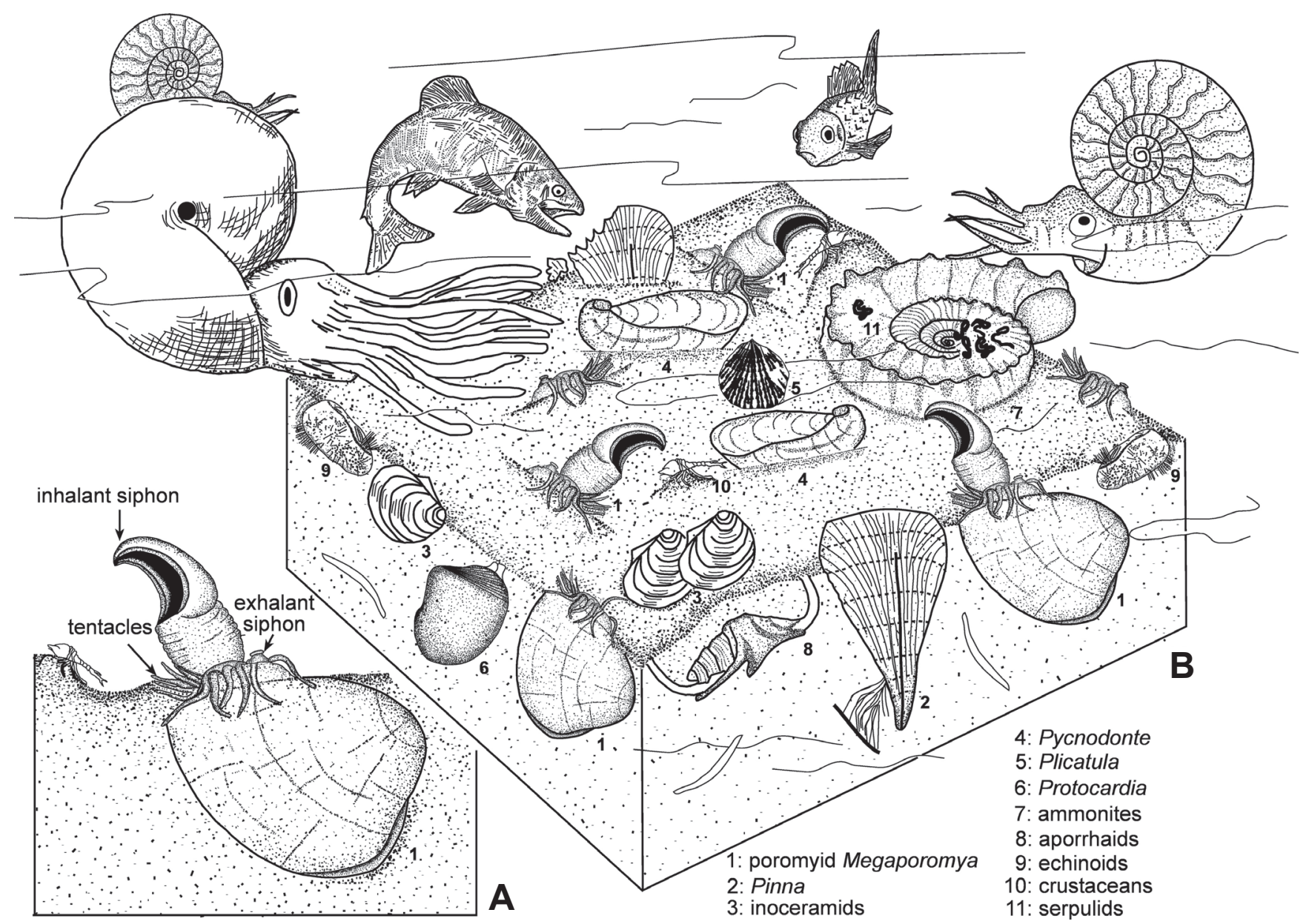

Figure 11. A, reconstruction of life and feeding modes of Megaporomya reymenti gen. et sp. nov. by analogy with modern relatives (e.g. Yonge, 1928; Allen \& Morgan, 1981; Morton, 1984); B, environmental reconstruction showing Megaporomya with other bivalve groups, gastropods and echinoids.

the abundance of inoceramids, the water depth of the Sergipe Basin decreased from the early to late Turonian. In the earlymiddle Turonian, the fauna was dominated by inoceramids and ammonites, which decrease in abundance in the late Turonian with a corresponding increase in non-inoceramid bivalves, gastropods and echinoids.

\section{CONCLUSIONS}

The bivalve Megaporomya reymenti gen. et sp. nov. (Pholadomyida, Poromyidae) is described from the upper Turonian of the Cotinguiba Formation of the Sergipe Basin in north-eastern Brazil. 
The main morphological features that distinguish Megaporomya gen. nov. from other poromyid genera are the very large size $(\mathrm{L}=85-140 \mathrm{~mm})$, wide umbonal area, thick pallial line with shallow sinus, wide posterior gape, strongly inflated valves, and the presence of one large, inverted, U-shaped cardinal tooth, one straight and narrow cardinal tooth and two unequal sockets in the right valve.

Based on analogy with Recent relatives, Megaporomya gen. nov. is interpreted as a semi-infaunal predator, burrowing in soft substrates with its posterior end slightly extending above the sediment-water interface. It detected its prey with the help of specialized feeding tentacles surrounding the inhalant siphon (Figure 11A).

The co-occurrence of Megaporomya reymenti gen. et sp. nov. with stenohaline organisms such as echinoids and ammonites indicates a fully marine environment. In addition, the dominance of suspension-feeders indicates moderately high water energy and a relatively low sedimentation rate. The nearly equal abundance of epifaunal and shallow-infaunal organisms is evidence of a moderately soft substrate.

\section{ACKNOWLEDGEMENTS}

The authors greatly appreciate the thoughtful reviews and valuable suggestions of L.R.L. Simone (Museu de Zoologia, Universidade de São Paulo) and L.E. Anelli (Instituto de Geociências, Universidade de São Paulo). Great thanks are also due to M.-L. Neufert and B. Leipner-Mata (Institut für Paläontologie, Universität Erlangen-Nürnberg, Germany) for the photographic work and for preparing the polished slabs and silicone moulds, respectively. P.B. thanks S.I. Bengtson (Heidelberg), D.A. Campos (DNPM, Rio de Janeiro) and Petrobras S.A. (Aracaju and Rio de Janeiro) for field and logistic assistance. The fieldwork was financed mainly by the Swedish Natural Science Research Council (NFR, now Vetenskapsrådet, VR). E.J.A. is grateful for the support of the German Academic Exchange Service (DAAD) and to M.J. Andrade (Aracaju, Brazil) for assistance in the field.

\section{REFERENCES}

Allen, J.A. \& Morgan, R.E. 1981. The functional morphology of Atlantic deep water species of the families Cuspidariidae and Poromyidae (Bivalvia): an analysis of the evolution of the septibranch condition. Philosophical Transactions of the Royal Society of London, Series B, 294:413-546. doi:10.1098/ rstb.1981.0117

Andrade, E.J. 2005. Turonian inoceramids and biostratigraphy of the Sergipe Basin, northeastern Brazil: an integrated study of the Votorantim and Nassau quarries. Heidelberg University, Ph.D. thesis, $155 \mathrm{p}$.

Andrade, E.J. \& Santos, M.T.M. 2011. Moluscos biválvios do Turoniano (Cretáceo Superior) da Bacia de Sergipe. In: I.S. Carvalho; N.K. Srivastava; O. Strohschoen Jr. \& C.C. Lana (eds.) Paleontologia: Cenários de Vida, Volume 4, Rio de Janeiro, Interciência, p. 229-238.

Andrade, E.J.; Seeling, J.; Bengtson, P. \& Souza-Lima, W. 2004. The bivalve Neithea from the Cretaceous of Brazil. Journal of South American Earth Sciences, 17:25-38.
Barber, W. 1958. Upper Cretaceous Mollusca from north-eastern Nigeria. Records of the Geological Survey of Nigeria, 1956: 14-37.

Bengtson, P. 1983. The Cenomanian-Coniacian of the Sergipe Basin, Brazil. Fossils and Strata, 12:1-78.

Bengtson, S.I.; Bengtson, P. \& Andrade, E.J. 2005. A revised ammonite biostratigraphy for the upper Turonian-lower Coniacian of the Sergipe Basin, Brazil. In: CONGRESSO BRASILEIRO DE PALEONTOLOGIA, 19/CONGRESSO LATINO-AMERICANO DE PALEONTOLOGIA, 4, 2005. Resumo, Aracaju, SBP, UFS, CD-ROM.

Beurlen, K. 1971. Beiträge zur Paläogeographie der Kreide in Nordost-Brasilien. Neues Jahrbuch für Geologie und Paläontologie, Abhandlungen, 139:1-28.

Bieler, R.; Carter, J.G. \& Coan, E.V. 2010. Classification of bivalve families. In: P. Bouchet \& J.P. Rocroi. Malacologia, 52:113-184.

Cox, L.R. 1969. General features of Bivalvia. In: R.C. Moore (ed.) Treatise on Invertebrate Paleontology: Part N, Mollusca 6, Bivalvia, University of Kansas Press, p. N2-N128.

Dhondt, A. \& Jagt, J.W.M. 1989. Upper Cretaceous Liopistha species in north western Europe. Bulletin de l'Institut Royal des Sciences Naturelles de Belgique, Sciences de la Terre, 58 [for 1988]: 187-197.

Elder, W.P. 1987. The paleoecology of the Cenomanian-Turonian (Cretaceous) stage boundary extinctions at Black Mesa, Arizona. Palaios, 2:22-40.

Feijó, F.J. 1995. Bacias de Sergipe e Alagoas. Boletim de Geociências da Petrobrás, 8 [for 1994]:149-161.

Fürsich, F.T. 1980. Preserved life positions of some Jurassic bivalves. Paläontologische Zeitschrift, 54:289-300.

Hammer, Ø.; Harper, D.A.T. \& Ryan, P.D. 2001. PAST: Paleontological statistics software package for education and data analysis. Palaeontologia Electronica, 4(1), http://palaeoelectronica.org/2001_1/past/issue1_01.htm

Harper, E.; Dreyer, H. \& Steiner, G. 2006. Reconstructing the Anomalodesmata (Mollusca: Bivalvia): morphology and molecules. Zoological Journal of the Linnean Society, 148:395-420. doi:10.1111/j.1096-3642.2006.00260.x

Hessel, M.H.R. 1985. Alguns inoceramídeos (Bivalvia) radialmente ondulados do Turoniano inferior de Sergipe. Coletânea de Trabalhos Paleontológicos, Brasília, Departamento Nacional de Produção Mineral, p. 227-237. (Série Geologia 27, Seção Paleontologia e Estratigrafia 2).

Hessel, M.H.R. 1988. Lower Turonian inoceramids from Sergipe, Brazil: systematics, stratigraphy and palaeoecology. Fossils and Strata, 22:1-49.

Kauffman, E.G. \& Bengtson, P. 1985. Mid-Cretaceous inoceramids from Sergipe, Brazil: a progress report. Cretaceous Research, 6:311-315. doi:10.1016/0195-6671(85)90053-9

Koutsoukos, E.A.M. \& Bengtson, P. 1993. Towards an integrated biostratigraphy of the Aptian-Maastrichtian of the Sergipe Basin, Brazil. Documents du Laboratoire de Géologie de Lyon, 125:241-262.

Koutsoukos, E.A.M.; Destro, N., Azambuja Filho, N.C. \& Spadini, A.R. 1993. Upper Aptian-lower Coniacian carbonate sequences in the Sergipe Basin, northeastern Brazil. In: T. Simo, B. Scott \& J.P. Masse (eds.) Cretaceous carbonate platforms. American Association of Petroleum Geologists, p. 127-144 (Memoir 56).

Koutsoukos, E.A.M.; Mello, M.R. \& Azambuja Filho, N.C. 1991. Micropalaeontological and geochemical evidence of MidCretaceous dysoxic-anoxic environments in the Sergipe Basin, northeastern Brazil. In: R.V. Tyson \& T.H. Pearson (eds.) Modern and ancient continental shelf anoxia. Geological Society of London, 58:427-447. 
Manso, C.L.C. \& Andrade, E.J. 2008. Equinóides do Turoniano (Cretáceo Superior) de Sergipe, Brasil. Geociências, 27:319-327.

Maury, C.J. 1925. Fosseis terciarios do Brasil, com descripção de novas formas cretaceas. Serviço Geologico e Mineralogico, p. 1-711 (Monographia 4).

Maury, C.J. 1937. O Cretaceo de Sergipe. Serviço Geologico e Mineralogico do Brasil, p. 1-283 (Monographia 11).

Morton, B. 1981. Prey capture in the carnivorous septibranch Poromya granulata (Bivalvia: Anomalodesmata: Poromyacea). Sarsia, 66:241-256.

Morton, B. 1984. Prey capture in Lyonsiella formosa (Bivalvia: Anomalodesmata: Verticordiacea). Pacific Science, 38:283-297.

Ojeda, H.A.O. 1982. Structural framework, stratigraphy and evolution of Brazilian marginal basins. Bulletin of the American Association of Petroleum Geologists, 66:732-749.

Ojeda, H.A.O. \& Fugita, A.M. 1976. Bacia Sergipe/Alagoas: geologia regional e perspectivas petrolíferas. In: CONGRESSO BRASILEIRO DE GEOLOGIA, 28, 1974. Anais, Porto Alegre, SBP, p. 137-138.

Pelseneer, P. 1891. Contribution à l'étude des Lamellibranches. Archives de Biologie, 11:147-312.

Pervinquière, L. 1912. Études de paléontologie tunisienne: II. Gastéropodes et Lamellibranches des terrains crétacés. Paris, Carte géologique de la Tunisie, 352 p.

Ponte, F.C. Fonseca, J.R. \& Carozzi, A.V. 1980. Petroleum habitats in the Mesozoic-Cenozoic of the continental margin of Brazil. In: A.D. Miall (ed.) Facts and principles of world petroleum occurrence. Memoir of the Canadian Society of Petroleum Geologists, 6:857-886.

Reyment, R.A. \& Tait, E.A. 1972. Biostratigraphical dating of the early history of the South Atlantic Ocean. Philosophical Transactions of the Royal Society of London, Series B: Biological Sciences, 264:55-95. doi:10.1098/rstb.1972.0009

Riedel, L. 1932. Die Oberkreide vom Mungofluß in Kamerun und ihre Fauna. Beiträge zur geologischen Erforschung der deutschen Schutzgebiete, 16:1-154.

Runnegar, B. 1974. Evolutionary history of the bivalve subclass Anomalodesmata. Journal of Paleontology, 48:904-939.

Schaller, H. 1970. Revisão estratigráfica da Bacia de Sergipe/ Alagoas. Boletim Técnico da Petrobrás, 12 [for 1969]:21-86.

Seeling, J. 1999. Palaeontology and biostratigraphy of the macroinvertebrate fauna of the Cenomanian-Turonian transition of the Sergipe Basin, northeastern Brazil, with systematic descriptions of bivalves and echinoids. Heidelberg University, Ph.D. thesis, $185 \mathrm{p}$.

Seeling, J. 2004: Bioerosion of Late Cretaceous molluscs from Sergipe, Brazil. Neues Jahrbuch für Geologie und Paläontologie, Monatshefte, 2004:413-426.
Seeling, J. \& Bengtson, P. 1999. Cenomanian oysters from the Sergipe Basin, Brazil. Cretaceous Research, 20:747-765. doi: 10.1006/cres.1999.0190

Seeling, J. \& Bengtson, P. 2003a. The bivalve Pinna cretacea (Schlotheim, 1813) from the Cretaceous of Brazil. Acta Palaeontologica Polonica, 48:475-480.

Seeling, J. \& Bengtson, P. 2003b. The Late Cretaceous bivalve Didymotis Gerhardt, 1897 from Sergipe, Brazil. Paläontologische Zeitschrift, 77:153-160.

Smith, A.B. \& Bengtson, P. 1991. Cretaceous echinoids from northeastern Brazil. Fossils and Strata, 31:1-88.

Souza-Lima, W., Andrade, E.J., Bengtson, P. \& Galm, P.C. 2002. A bacia de Sergipe-Alagoas: Evolução geológica, estratigráfica e conteúdo fóssil - The Sergipe-Alagoas Basin: Geological evolution, stratigraphy and fossil content. Fundação Paleontológica Phoenix, Edição especial, 1:1-34.

Stanley, S.M. 1970. Relation of shell form to life habits of the Bivalvia (Mollusca). Geological Society of America Memoir, 125:1-296.

Stanley, S.M. 1972. Functional morphology and evolution of byssally attached bivalve mollusks. Journal of Paleontology, 46:165-212.

Stanley, S.M. 1975. Adaptive themes in the evolution of the Bivalvia (Mollusca). Annual Review of Earth and Planetary Sciences, 3:361-385. doi: 10.1146/annurev.ea.03.050175.002045

Stoliczka, F. 1871. Cretaceous fauna of southern India: the Pelecypoda, with a review of all known genera of this class, fossil and Recent. Memoirs of the Geological Survey of India, Palaeontologia Indica, 3:1-537.

Trueman, E.R. 1967. The dynamics of burrowing in Ensis (Bivalvia). Proceedings of the Royal Society of London, B: Biological Sciences, 166:459-476. doi:10.1098/rspb.1967.0007

White, C.A. 1887. Contribuições á paleontologia do Brazil. Archivos do Museu Nacional do Rio de Janeiro, 7:1-273.

Whitney, M.I. 1952. Some zone marker fossils of the Glen Rose Formation of central Texas. Journal of Paleontology, 26:65-73.

Woods, H. 1909. A monograph of the Cretaceous Lamellibranchia of England. Monographs of the Palaeontographical Society, 63:217-260.

Yonge, C.M. 1928. Structure and function of the organs of feeding and digestion in the septibranchs, Cuspidaria and Poromya. Philosophical Transactions of the Royal Society of London, Series B, 216:221-263. doi:10.1098/rstb.1928.0004

Yonge, C.M. \& Morton, B. 1980. Ligament and lithodesma in the Pandoracea and Poromyacea with a discussion on the evolutionary history of the Anomalodesmata (Mollusca: Bivalvia). Journal of Zoology, 191:263-292. doi:10.1111/j.1469-7998.1980.tb01459.x

Received in May, 2013; accepted in August, 2013. 
Appendix. Dimensions $(\mathrm{mm})$ of measurable specimens of Megaporomya reymenti gen. et sp. nov. from the upper Turonian of the Sergipe Basin. For abbreviations, see Figure 3.

\begin{tabular}{|c|c|c|c|c|c|c|c|c|c|}
\hline Sample no. & L & $\mathrm{H}$ & W & $\mathrm{Al}$ & $\mathrm{Hs}$ & C & $\mathrm{H} / \mathrm{L}$ & $\mathrm{Al} / \mathrm{L}$ & W/L \\
\hline MN 8711-I & 150 & 105 & 97 & 45 & 83 & 170 & 0.70 & 0.30 & 0.65 \\
\hline MN 8713-I & 98 & 80 & 72 & 30 & 59 & 115 & 0.82 & 0.31 & 0.73 \\
\hline MN 8714-I & 110 & 85 & 80 & 21 & 52 & 143 & 0.77 & 0.19 & 0.73 \\
\hline MN 8715-I & 115 & 85 & 70 & 32 & 58 & 154 & 0.74 & 0.28 & 0.61 \\
\hline MN 8717-I & 113 & 83 & 77 & 32 & 65 & 150 & 0.73 & 0.28 & 0.68 \\
\hline MN 8718-I & 119 & 105 & 93 & 44 & 79 & 163 & 0.88 & 0.37 & 0.78 \\
\hline MN 8719-I & 105 & 83 & 82 & 27 & 53 & 155 & 0.79 & 0.26 & 0.78 \\
\hline MN 8722-I & 101 & 95 & 87 & 45 & 66 & 130 & 0.94 & 0.45 & 0.86 \\
\hline MN 8723-I & 105 & 98 & 88 & 40 & 67 & 150 & 0.93 & 0.38 & 0.84 \\
\hline MN 8724-I & 110 & 102 & 89 & 38 & 64 & 165 & 0.93 & 0.35 & 0.81 \\
\hline MN 8725-I & 100 & 98 & 93 & 38 & 73 & 135 & 0.98 & 0.38 & 0.93 \\
\hline MN 8726-I & 123 & 98 & 80 & 34 & 78 & 130 & 0.80 & 0.28 & 0.65 \\
\hline MN 8727-I & 116 & 85 & 87 & 22 & 70 & 153 & 0.73 & 0.19 & 0.75 \\
\hline MN 8728-I & 99 & 78 & 70 & 12 & 61 & 120 & 0.79 & 0.12 & 0.71 \\
\hline MN 8729-I & 92 & 78 & 67 & 28 & 51 & 115 & 0.85 & 0.30 & 0.73 \\
\hline MN 8730-I & 118 & 88 & 88 & 20 & 66 & 150 & 0.75 & 0.17 & 0.75 \\
\hline MN 8731-I & 95 & 82 & 60 & 32 & 55 & 115 & 0.86 & 0.34 & 0.63 \\
\hline MN 8732-I & 100 & 94 & 73 & 42 & 56 & 133 & 0.94 & 0.42 & 0.73 \\
\hline MN 8733-I & 135 & 100 & 90 & 17 & 60 & 170 & 0.74 & 0.13 & 0.67 \\
\hline MN 8734-I & 100 & 78 & 71 & 18 & 55 & 120 & 0.78 & 0.18 & 0.71 \\
\hline MN 8735-I & 117 & 90 & 83 & 30 & 58 & 153 & 0.77 & 0.26 & 0.71 \\
\hline MN 8736-I & 115 & 85 & 84 & 17 & 65 & 145 & 0.74 & 0.15 & 0.73 \\
\hline MN 8737-I & 122 & 91 & 89 & 33 & 60 & 165 & 0.75 & 0.27 & 0.73 \\
\hline MN 8739-I & 85 & 73 & 60 & 25 & 50 & 113 & 0.86 & 0.29 & 0.71 \\
\hline MN 8741-I & 120 & 83 & 87 & 30 & 60 & 155 & 0.69 & 0.25 & 0.73 \\
\hline MN 8742-I & 118 & 94 & 85 & 42 & 63 & 140 & 0.80 & 0.63 & 0.72 \\
\hline MN 8743-I & 120 & 97 & 90 & 29 & 67 & 155 & 0.81 & 0.24 & 0.75 \\
\hline MN 8744-I & 120 & 90 & 86 & 33 & 73 & 155 & 0.75 & 0.28 & 0.72 \\
\hline MN 8745-I & 150 & 92 & 100 & 32 & 65 & 170 & 0.61 & 0.21 & 0.67 \\
\hline MN 8746-I & 107 & 98 & 80 & 45 & 60 & 130 & 0.92 & 0.42 & 0.75 \\
\hline MN 8747-I & 141 & 110 & 98 & 45 & 69 & 172 & 0.78 & 0.32 & 0.0 \\
\hline MN 8748-I & 130 & 95 & 100 & 20 & 68 & 155 & 0.73 & 0.15 & 0.77 \\
\hline MN 8749-I & 115 & 97 & 90 & 17 & 63 & 148 & 0.84 & 0.15 & 0.78 \\
\hline SMNK-PAL 11001 & 103 & 80 & 86 & 14 & 71 & 150 & 0.78 & 0.14 & 0.83 \\
\hline SMNK-PAL 11002 & 106 & 90 & 78 & 45 & 60 & 135 & 0.85 & 0.42 & 0.74 \\
\hline SMNK-PAL 11005 & 140 & 100 & 105 & 15 & 78 & 175 & 0.71 & 0.11 & 0.75 \\
\hline SMNK-PAL 11008 & 105 & 97 & 75 & 36 & 68 & 135 & 0.92 & 0.34 & 0.71 \\
\hline SMNK-PAL 11009 & 118 & 102 & 77 & 45 & 58 & 135 & 0.86 & 0.38 & 0.65 \\
\hline SMNK-PAL 11010 & 108 & 80 & 76 & 10 & 70 & 143 & 0.74 & 0.09 & 0.70 \\
\hline SMNK-PAL 11013 & 120 & 97 & 97 & 25 & 60 & 175 & 0.81 & 0.21 & 0.81 \\
\hline SMNK-PAL 11014 & 120 & 113 & 98 & 42 & 66 & 180 & 0.94 & 0.35 & 0.82 \\
\hline SMNK-PAL 11016 & 106 & 96 & 87 & 40 & 60 & 135 & 0.91 & 0.38 & 0.82 \\
\hline SMNK-PAL 11018 & 118 & 85 & 85 & 20 & 63 & 165 & 0.72 & 0.17 & 0.72 \\
\hline SMNK-PAL 11021 & 125 & 95 & 89 & 35 & 75 & 148 & 0.76 & 0.28 & 0.71 \\
\hline SMNK-PAL 11023 & 104 & 98 & 89 & 30 & 65 & 145 & 0.94 & 0.29 & 0.86 \\
\hline SMNK-PAL 11024 & 118 & 78 & 85 & 15 & 74 & 160 & 0.66 & 0.13 & 0.72 \\
\hline SMNK-PAL 11025 & 108 & 102 & 90 & 41 & 47 & 135 & 0.94 & 0.38 & 0.83 \\
\hline SMNK-PAL 11027 & 130 & 83 & 87 & 30 & 58 & 165 & 0.64 & 0.23 & 0.67 \\
\hline SMNK-PAL 11029 & 120 & 83 & 85 & 17 & 70 & 155 & 0.69 & 0.14 & 0.71 \\
\hline
\end{tabular}


Appendix. Cont.

\begin{tabular}{lccccccccc}
\hline Sample no. & $\mathrm{L}$ & $\mathrm{H}$ & $\mathrm{W}$ & $\mathrm{Al}$ & $\mathrm{Hs}$ & $\mathrm{C}$ & $\mathrm{H} / \mathrm{L}$ & $\mathrm{Al} / \mathrm{L}$ & $\mathrm{W} / \mathrm{L}$ \\
\hline SMNK-PAL 11029 & 109 & 85 & 82 & 13 & 65 & 136 & 0.78 & 0.12 & 0.75 \\
SMNK-PAL 11030 & 120 & 113 & 98 & 35 & 75 & 163 & 0.94 & 0.29 & 0.82 \\
SMNK-PAL 11031 & 132 & 85 & 95 & 30 & 74 & 175 & 0.64 & 0.23 & 0.72 \\
SMNK-PAL 11032 & 125 & 87 & 94 & 14 & 65 & 175 & 0.70 & 0.11 & 0.75 \\
SMNK-PAL 11033 & 115 & 102 & 73 & 37 & 68 & 135 & 0.89 & 0.32 & 0.63 \\
SMNK-PAL 11034 & 115 & 95 & 85 & 25 & 60 & 150 & 0.83 & 0.22 & 0.74 \\
SMNK-PAL 11035 & 120 & 89 & 88 & 25 & 72 & 150 & 0.74 & 0.21 & 0.73 \\
SMNK-PAL 11036 & 102 & 76 & 78 & 18 & 67 & 130 & 0.75 & 0.18 & 0.76 \\
\hline
\end{tabular}

